\title{
ASSOCIATIVE BEHAVIOUR IN PRZEWALSKI'S HORSES REINTRODUCED INTO MONGOLIA
}

\author{
Sarah R. B. King ${ }^{1,2, *}$, John Gurnell ${ }^{1}$ \\ ${ }^{1}$ Queen Mary University of London, United Kingdom \\ ${ }^{2}$ Colorado State University, USA \\ *e-mail:sarah.king@colostate.edu
}

Received: 04.04.2019. Revised: 30.04.2019. Accepted: 04.05.2019.

\begin{abstract}
Allogrooming is an important associative behaviour in social mammals that has hygienic and/or social functions and may be mediated by kin selection or reciprocity. Equids exhibit allogrooming and another associative behaviour, stand resting in close proximity. We examined patterns in these behaviours in four harems of Przewalski horses Equus ferus przewalskii, reintroduced into Mongolia to assess whether they were simply reciprocal behaviours that had a hygienic rather than a social function. We conducted 860 hours of observation over 15 months between April 1998 and July 2000. Allogrooming was infrequent (median frequency of 0.02 acts horse $^{-1} \times$ hour $^{-1}, \mathrm{n}=363$ acts, IQR $=0-0.06$ ), occurring more on the withers ( $62 \%$ of observations) than any other body part. Allogrooming was more frequent in spring and autumn, and morning and evening. There were no significant correlations between relatedness of partners, dominance rank, tenure length, whether individuals changed group, age or aggressive behaviour and the frequency of allogrooming in any harem. Stand resting together was less frequent than allogrooming (median frequency of 0.00 acts horse ${ }^{-1} \times$ hour $^{-1}, \mathrm{n}=335$, IQR $=$ $0-0.014)$. In contrast to allogrooming, stand resting together was confined to spring and occurred more during the middle of the day. There were no significant differences between harems, between relatedness and the frequency of stand resting together within any harem, and with age and tenure. In all, we found no evidence of a social function of either allogrooming or stand resting together, but both occurred most frequently at times of the year when they would be needed for coat care or to reduce flies around the face. Our results support our hypothesis that associative behaviours were simply reciprocal hygienic arrangements with no evidence that kin selection was involved, although a social element to the behaviours cannot be completely ruled out.
\end{abstract}

Key words: allogrooming, Equus ferus przewalskii, hygiene, mutual grooming, reciprocity, relatedness

\section{Introduction}

Allogrooming has been commonly observed in social mammals, such as carnivores (e.g. van den Bos, 1998; Kutsukake \& Clutton-Brock, 2006, 2010; Dugdale et al., 2010), primates (e.g. Barton, 1985; Dunbar, 1991; Di Biletti, 1997; Schino \& Aureli, 2010), rodents (Hillegass et al., 2008; Mott et al., 2011) and ungulates (Mooring \& Hart, 1992; Matsuno \& Urabe, 1999; Mooring et al., 2000). Many studies have focused on whether such behaviour has a purely hygienic function, or whether it also has evolved a more social significance (Dunbar, 1991). In a hygienic context, grooming removes ticks and other external parasites, which can spread pathogens as well as result in a loss of blood or cause secondary infections or other complications (Mooring et al., 2000). Ticks, for example, can have a considerable effect on an animal: one study showed that a moderate tick load on calves resulted in $10 \mathrm{~kg}$ to $44 \mathrm{~kg}$ reductions in weight gain per year (Norval et al., 1988). The utilitarian function of hygienic grooming is evident when it is seen to focus on areas of the body that the recipient cannot reach by self grooming (Barton, 1985; Hart \& Hart, 1992; Stewart \& Macdonald, 2003; Lewis, 2010). In a social context, grooming may be traded for direct benefits in a reciprocal grooming arrangement that may or may not involve close relatives (e.g. Hart \& Hart, 1992; Schino \& Aureli, 2010) or be traded for other social benefits, such as tolerance from more dominant animals or the maintenance of social relationships (Sato et al., 1993; Henzi \& Barrett, 1999; Gumert, 2007; Schino, 2007). Nonetheless, allogrooming carries costs as well as benefits including: tooth wear, loss of water in saliva, a reduction in feeding or a reduction in vigilance behaviour (Hart \& Hart, 1992; Mooring \& Hart, 1995; Henzi \& Barrett, 1999).

Social interaction other than aggression is quite rare in equids (Wells \& von Goldschmidt-Rothschild, 1979) but is expressed by allogrooming (often termed mutual grooming) or by horses standing in close proximity - together these behaviours are re- 
ferred to as associative behaviours. It has been presupposed that associative behaviour in horses has an almost entirely social function (Wells \& von Goldschmidt-Rothschild, 1979; Feh \& de Mazieres, 1993; Kimura, 1998) strengthening the bonds between individuals or family members (Feist \& McCullough, 1976; Crowell-Davis et al., 1986), and was observed to be more common in summer than other times of the year, when horses stay closer together (Kimura, 1998). However, there are conflicting reports in the literature as to whether associative behaviour occurs most frequently between kin (Wells \& von Goldschmidt-Rothschild 1979; Houpt \& Boyd, 1994), or between animals of similar age and rank (Keiper, 1988; Keiper \& Receveur, 1992; Sigurjónsdóttir et al., 2003), or whether there is little influence of rank or kin (Clutton-Brock et al., 1976; Mooring \& Hart, 1995). Allogrooming has been reported to appease individuals, either to ameliorate aggression (Feist \& McCullough, 1976; Feh \& de Mazieres, 1993), to reduce social tension by reducing the heart rate (Schino et al., 1988; Feh \& de Mazieres, 1993) or to reduce weaning conflict (Penzhorn, 1984; Keiper, 1988). A social function of allogrooming in horses is also indicated in a study where more allogrooming was seen in a new group than in an established group of horses in an area with few parasites (Feh \& Carton de Graumont, 1995). Associations between horses in a harem affect its cohesiveness. Horses tend to have preferred adult partners for grazing and resting (Clutton-Brock et al., 1976; Kimura, 1998), although overall foals remain closer to their mothers than to any other horse (Carson \& Wood-Gush, 1983). Most equid populations have a stable female membership of harems from one year to the next (see Penzhorn (1984) for mountain zebras Equus zebra Linnaeus, 1758; Linklater (2000) for feral horses Equus ferus caballus Boddaert, 1785), although movement of adult mares between harems also occurs, even independently of influences of the stallion (Keiper, 1976; King, personal observation).

This aim of this study was to assess whether there are patterns in associative behaviour (al- logrooming and standing in close proximity) in relation to kin, sex, age and dominance among members of four harems of Przewalski's horses, E. f. przewalskii Poliakov, 1881, reintroduced into Mongolia (see King, 2002; King \& Gurnell, 2005, $2007,2010)$. In doing so, we wish to contribute to the debate about the function of associative behaviours in equids including whether they are mediated by kin selection or simply by reciprocity.

\section{Study site}

All fieldwork was carried out at Hustai National Park (HNP), Mongolia, between June 1998 and July 2000. The population of free-ranging Przewalski horses ranged from 70 to 94 horses in four to nine harems and a bachelor group during the study period. HNP is situated about $150 \mathrm{~km}$ south west of Ulaanbaatar, the capital city of Mongolia. At the time of the study it covered $570 \mathrm{~km}^{2}$ along a south western spur of the Khentei range of mountains (around the geographical coordinates: $47.6833 \mathrm{~N}$, 105.9000 E). The park borders the River Tuul, and has an altitude of between $1100 \mathrm{~m}$ and $1842 \mathrm{~m}$. The climate is continental with a mean annual temperature of $+0.2^{\circ} \mathrm{C}$ and a yearly precipitation of $270 \mathrm{~mm}$, most of which falls as rain in the summer (Wallis de Vries et al., 1996). During the study period horses were observed in temperatures of between $-14^{\circ} \mathrm{C}$ and $+34^{\circ} \mathrm{C}$. HNP has a mountain forest steppe habitat and water flows down most of the major valleys as streams (Wallis de Vries et al., 1996).

\section{Study animals}

All horses brought to HNP came from reserves in Europe and the Ukraine. Upon arrival the horses were released as a harem into acclimatisation enclosures of about $0.4 \mathrm{~km}^{2}$ which were visually separated from each other. The horses were allowed to acclimatise for up to two years before being released from the enclosures. Harems will be referred to by the name of the dominant stallion; the composition of the study harems and their release dates are shown in Table 1.

Table 1. Przewalski's horse harems observed during the three years of this study (1998, 1999, and 2000) at Hustai National Park, Mongolia

\begin{tabular}{lcccccccccc}
\hline \multicolumn{1}{c}{ Stallion } & Year of release & \multicolumn{3}{c}{ Adult mares } & \multicolumn{3}{c}{ Juveniles (1-3 years old) } & \multicolumn{2}{c}{ Foals $(<1$ year old) } \\
\hline & & 1998 & 1999 & 2000 & 1998 & 1999 & 2000 & 1998 & 1999 & 2000 \\
Khaan & 1994 & 8 & 4 & - & 5 & 1 & - & 4 & 2 & - \\
Paritet & 1995 & 5 & 7 & 7 & 1 & 3 & 6 & 2 & 3 \\
Bayan & 1998 & 5 & 6 & 5 & 0 & 1 & 3 & 1 & 2 & 3 \\
Margad & $*$ & - & 5 & 7 & - & 4 & 4 & - & 1 & 3 \\
\hline
\end{tabular}

Note: * Margad was a Hustai-born bachelor stallion who acquired some of Khaan's mares in early 1999. Khaan's remaining mares were taken by another stallion later in the year. 


\section{Field observations and data analysis}

In 15 months of fieldwork between April 1998 and July 2000, four harems were observed for a total of about 860 hours. The standard observation procedure was that a harem would be found at or close to dawn and then followed until 2:00 p.m. The same harem was then found at 2:00 p.m. the next day and followed until dusk. In this way observations of the harems were made from dawn to dusk. The horses could normally be watched on foot from a distance of about $15 \mathrm{~m}$ once they were accustomed to the presence of the observer. All animals could be individually identified by size and pelage characteristics. Behavioural observations were recorded on a microcassette recorder in the field as they occurred. All observations were carried out by a single observer.

In a preliminary study in 1998 all occurrences (Altmann, 1974) of the associative behaviours allogrooming and stand resting together were recorded, plus the duration of allogrooming bouts to the nearest second. In 1999 and 2000 scan sampling (Altmann, 1974) was conducted every minute during observations for occurrences of allogrooming or stand resting together, as the preliminary study showed that few bouts would be missed; duration was therefore to the nearest minute. Allogrooming was defined as when two horses stood head to tail and chewed or nuzzled each other's coats (Boyd \& Houpt, 1994) and was therefore always symmetrical; non-reciprocal grooming was only seen once during observation sessions. Stand resting together occurred when the horses were standing head to tail within one metre of each other. The names of the horses grooming each other or stand resting together were recorded, along with the initiator if seen, and part of the body groomed. These data are described below, but not included in analyses. Agonistic behaviour of the animals was also studied; in 1998 all agonistic events were recorded to the nearest minute; in 1999 and 2000 to the nearest second. The name of the aggressor and recipient of aggression and the outcome of the event were recorded, plus the behaviour used by the aggressor and any retaliation by the recipient.

The coefficient of relatedness (r) between individuals was determined from studbook data. Maternity, and paternity of horses originating from captive stock, were known. Paternity of horses born in HNP was assumed to be the stallion of the harem at the time of conception. Although sneak matings were possible, due to the small number of mature stallions present during this study these were unlikely.

Sample sizes were small, and we pooled the frequencies of associative behaviour across years for each harem. We used chi-squared tests to investigate whether there was any relationship between associative behaviour and month or hour of the day, and Kruskal-Wallis ANOVA to test for differences among the harems. In the case of allogrooming, the body part most groomed was also examined. We drew up matrices of the relatedness (the coefficient of relatedness $\langle\mathrm{r}\rangle)$ between each pair of animals in a harem, and the frequency of associative behaviours between each dyad, and calculated the correlation between these matrices for each harem using MatMan (Noldus Information Technology, 1998). We also carried out correlation analyses, (using Pearson's correlation coefficient for normally distributed data or Spearman's correlation coefficient for non-normal data) to explore possible relationships between associative behaviour and aggressiveness, total relatedness, age and tenure, as well as to examine duration of these behaviours. The frequencies of behavioural acts were positively skewed, and we present both median and mean descriptive statistics.

\section{Results}

\section{Frequency of associative behaviour}

Associative behaviour was infrequent with the median frequency of all acts over all years being 0.06 acts horse ${ }^{-1} \times$ hour $^{-1}(\mathrm{n}=773$ acts, IQR $=0.02$ 0.10 ; mean $=0.08$ acts horse ${ }^{-1} \times$ hour $^{1}, \mathrm{sd}=0.12$ ). Over the same time period the median frequency of aggressive behaviours was also low, at 0.22 acts horse $^{-1} \times$ hour $^{-1}(\mathrm{n}=988$ agonistic interactions, IQR $=0.05-0.48$; mean $=0.35$ acts horse ${ }^{-1} \times$ hour $^{-1}$, sd $=0.46)$. There was no significant difference in the frequency of associative behavioural acts among harems (Kruskal-Wallis $\mathrm{H}_{3}=1.99, \mathrm{p}=0.574$ ).

Besides allogrooming and stand resting together, the only other positive associative behaviours observed were: play ( $\mathrm{n}=41$ observations), a horse rubbing its head against another $(n=15$ observations), a horse resting its head on another ( $\mathrm{n}=3$ observations), grazing in very close proximity $(\mathrm{n}=$ 4 observations), one occurrence of horses sniffing noses on the focal observation, and one observation of a foal sniffing at and grooming a juvenile's face.

There was no correlation between partner matrices of allogrooming and stand resting together within any harem, suggesting that different partners were chosen for these two activities (Paritet - Spearman's $r_{s}=0.34$, Bayan $-r_{s}=0.43$, Margad $-r_{s}=0.20$, Khaan $-r_{s}=0.24$, all $p>0.05$ ). Most interactions occurred between mares and juveniles $\left(\mathrm{X}_{8}^{2}=72820, \mathrm{p}<0.0001\right)$ and stallions were only involved in $22 \%$ of all interactions (Table 2). The observations of stallion and juvenile interactions occurred between a single stallion-colt pair. 
Table 2. Associative interactions between Przewalski's horses of different ages and sexes at Hustai National Park, Mongolia. Per cent of the total number of observations $(n=$ 768 ), or per cent of the total between age/sex pairs that were related (full siblings or offspring)

\begin{tabular}{lcc}
\hline $\begin{array}{c}\text { Interaction between age } \\
\text { or sex class }\end{array}$ & \% Observations & \% Related \\
\hline Mare - Mare & 20 & 1 \\
Mare - Juvenile & 40 & 87 \\
Mare - Foal & 4 & 88 \\
Mare - Stallion & 19 & 0 \\
Stallion - Juvenile & 3 & 100 \\
Stallion - Foal & 0 & 0 \\
Juvenile - Foal & 4 & 10 \\
Juvenile - Juvenile & 6 & 67 \\
Foal - Foal & 4 & 0 \\
\hline
\end{tabular}

\section{Allogrooming}

Allogrooming was observed at a median frequency of 0.02 acts horse ${ }^{-1} \times$ hour $^{-1}(\mathrm{n}=363$ acts, IQR $=$ $0-0.06$; mean $=0.04$ acts horse ${ }^{-1} \times$ hour $^{-1}, \mathrm{sd}=0.06$ ). Median duration of allogrooming bouts was $1 \mathrm{~min}$. $(\mathrm{IQR}=1-2)$ and mean duration was $1.53 \mathrm{~min} .(\mathrm{sd}=$ 1.20). Allogrooming occurred significantly more on the withers (vertebrae at the base of the neck) than any other part of the body $(\mathrm{n}=373$; withers $62 \%$, back $14 \%$, shoulder $14 \%$, neck 5\%, haunch/rump 5\%; $\mathrm{X}_{6}$ $=746.2, \mathrm{p}<0.0001)$. There was also a significant difference in the time of day and time of year when there was a higher frequency of allogrooming. Allogrooming was more frequent in the spring and autumn (Fig. $\left.1 ; \mathrm{X}_{7}^{2}=227.59, \mathrm{p}<0.0001\right)$ and in the morning and evening (Fig. $2 ; \mathrm{X}_{16}^{2}=165.16, \mathrm{p}<0.0001$ ). There was no significant difference among the harems in the frequency of allogrooming $\left(\mathrm{H}_{3}=3.30, \mathrm{p}=0.348\right)$.

There was no significant correlation between relatedness (coefficient of relatedness $r$ ) and frequency of allogrooming within each harem matrix, thus closer related individuals did not groom each other more (Paritet - Pearson's $r=0.41$; Bayan $-r=0.31$; Margad $-r=0.54$; Khaan $-r=0.15$, all $p=>0.05$ ). Since stallions were only related to their offspring, with whom they had few interactions, we ran the correlations again with the stallion removed from the analysis. Still there were no significant correlations, except in Margad's harem ( $\mathrm{r}=0.57, \mathrm{p}=<0.05)$, but the value of $r$ was greater in all harems (Paritet $-r=$ 0.48 ; Bayan $-r=0.53$; Khaan $-r=0.21$, all $p>0.1$ ). There was no correlation between coefficient of relatedness and duration of allogrooming $\left(r_{s}=-0.1017\right.$, $\mathrm{p}=0.1177)$, and when related and unrelated dyads were compared, there was no difference in duration either $\left(\mathrm{H}_{88,150}=10711, \mathrm{p}=0.6781\right)$.

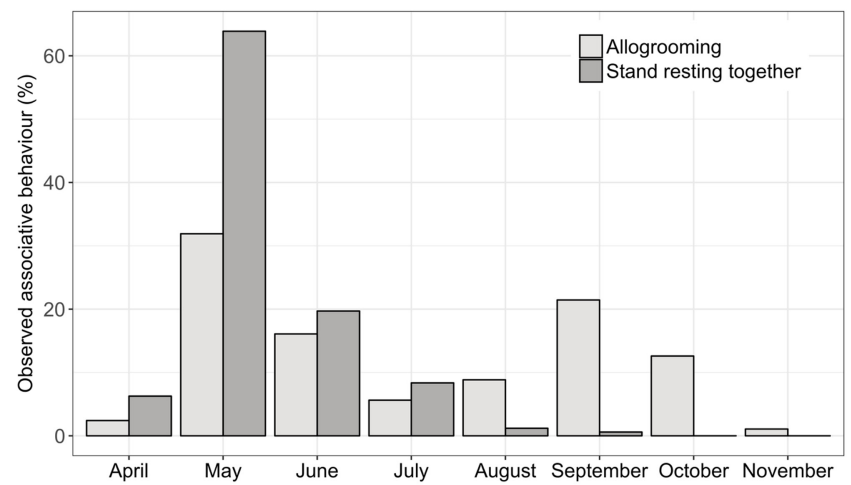

Fig. 1. Relative frequency (\%) of allogrooming (light grey bars) and stand resting together (dark grey bars) of Przewalski's horses at Hustai National Park, Mongolia according to month.

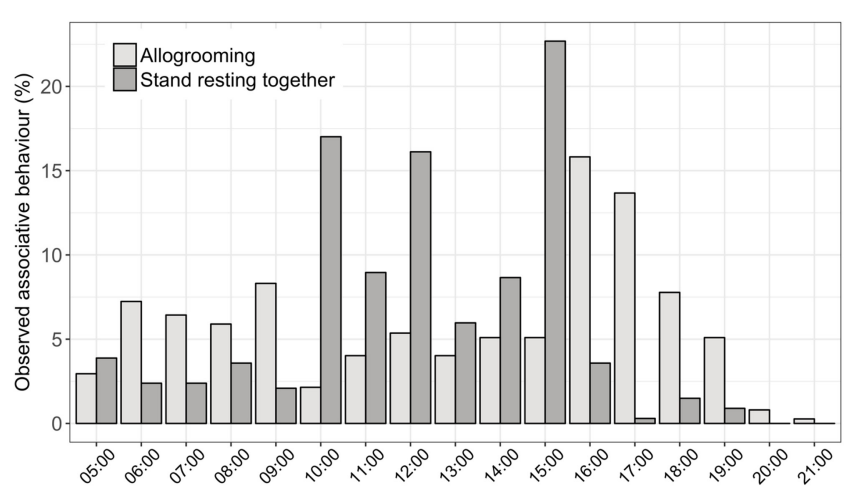

Fig. 2. Relative frequency (\%) of allogrooming (light grey bars) and stand resting together (dark grey bars) of Przewalski's horses at Hustai National Park, Mongolia according to hour of the day.

There was no correlation between allogrooming frequency and length of tenure in the harem, age or aggression (frequency of aggressive acts hour ${ }^{-1}$ ) in any harem when analysed both with and without the stallion (Table 3a,b). Margad's harem was the only one that showed a significant correlation between total relatedness (quantified as a sum of the coefficient of relatedness with all other harem members) to other members of the harem both with $(\mathrm{r}=0.67, \mathrm{n}=13, \mathrm{p}=0.013)$, and without $(\mathrm{r}=0.67, \mathrm{n}=12, \mathrm{p}=0.016)$ the stallion in the analysis. Overall, there was no correlation between dominance rank and allogrooming frequency $(\mathrm{r}=$ $0.118, \mathrm{n}=55, \mathrm{p}=0.392$ ).

Movement of individuals between groups was rare during this study (10 individuals dispersed or changed harem independent of a change in stallion). There was no difference in the frequency of allogrooming between adult horses that changed groups and those that did not $\left(\mathrm{H}_{9,29}=139, \mathrm{p}=\right.$ 0.2153 ), and there was high variation in frequency among individuals that moved. For example, of two mares that dispersed together, one had a frequency of 0.19 hour $^{-1}$ in the new harem, while the other 
had 0.0 hour $^{-1}$. A positive relationship was found between allogrooming and time since release $(r$ $=0.80, \mathrm{p}=0.0058)$, but not with the number of horses in the harem $(r=0.38, p=0.2287)$.

\section{Stand resting together}

Stand resting together was rare with a median frequency of 0.00 acts horse ${ }^{-1} \times$ hour $^{-1}(n=335$ acts, IQR $=0-0.014$, mean frequency was 0.03 acts horse $^{-1} \times$ hour $^{-1} \mathrm{sd}=0.108$ ). Median duration that horses stand rested together was 1 minute $(\mathrm{IQR}=$ 1-5.25) and mean duration was $5.27 \mathrm{~min}$. ( $\mathrm{sd}=$ 8.04). In contrast to allogrooming, stand resting was confined to the early summer (Fig. $1 ; \mathrm{X}^{2}{ }_{5}=585.89$, $\mathrm{p}<0.0001)$ and occurred more during the middle part of the day (Fig. 2; $\mathrm{X}^{2}{ }_{14}=325.98, \mathrm{p}<0.0001$ ).
There was no significant difference between the harems $\left(\mathrm{H}_{3}=5.82, \mathrm{p}=0.121\right)$, although Paritet and Margad tended to have a higher frequency than the other harems. There was no significant correlation between relatedness and frequency of stand resting together within any harem, although correlation coefficients were positive (Paritet $\mathrm{r}_{\mathrm{s}}=0.35$; Bayan $-\mathrm{r}_{\mathrm{s}}=0.29$; Margad $-\mathrm{r}_{\mathrm{s}}=0.14$; Khaan $-\mathrm{r}_{\mathrm{s}}=0.08$, all $\mathrm{p}=>0.1$ ). There was no correlation between coefficient of relatedness and duration of stand resting together $\left(r_{\mathrm{s}}=-0.1183\right.$, $\mathrm{p}$ $=0.3598$ ), and when related and unrelated dyads were compared, there was no difference in duration either $\left(\mathrm{H}_{25,37}=863, \mathrm{p}=0.2426\right)$. There was also no significant correlation between total relatedness, age and tenure for any harem (Table 4).

Table 3. Pearson's correlation coefficient between allogrooming frequency (events hour ${ }^{-1}$ ) and length of tenure in the harem, age or aggression (frequency of aggressive acts hour ${ }^{-1}$ ) in each Przewalski's horse harem observed at Hustai National Park, Mongolia. Significant results are italicised

(a) Including the stallion in the analysis

\begin{tabular}{lccccccccc} 
& \multicolumn{2}{c}{ Paritet $(\mathrm{n}=15)$} & \multicolumn{2}{c}{ Bayan $(\mathrm{n}=10)$} & \multicolumn{2}{c}{ Margad $(\mathrm{n}=13)$} & \multicolumn{2}{c}{ Khaan $(\mathrm{n}=17)$} \\
\cline { 2 - 9 } Factor & $\mathrm{r}$ & $\mathrm{p}$ & $\mathrm{r}$ & $\mathrm{p}$ & $\mathrm{r}$ & $\mathrm{p}$ & $\mathrm{r}$ & 0.718 \\
\hline Relatedness & -0.01 & 0.966 & -0.08 & 0.833 & 0.67 & 0.013 & -0.09 & 0.73 \\
Tenure & -0.36 & 0.193 & 0.16 & 0.659 & 0.07 & 0.823 & 0.22 & 0.407 \\
Age & -0.36 & 0.187 & 0.20 & 0.572 & -0.41 & 0.160 & 0.10 & 0.709 \\
Aggression & -0.15 & 0.604 & 0.07 & 0.846 & -0.30 & 0.314 & -0.17 & 0.508 \\
\hline
\end{tabular}

(b) Excluding the stallion in the analysis

\begin{tabular}{lccccccccc} 
& \multicolumn{2}{c}{ Paritet $(\mathrm{n}=14)$} & \multicolumn{2}{c}{ Bayan $(\mathrm{n}=9)$} & \multicolumn{2}{c}{ Margad $(\mathrm{n}=12)$} & \multicolumn{2}{c}{ Khaan $(\mathrm{n}=16)$} \\
\cline { 2 - 9 } Factor & $\mathrm{r}$ & $\mathrm{p}$ & $\mathrm{r}$ & $\mathrm{p}$ & $\mathrm{r}$ & $\mathrm{p}$ & $\mathrm{r}$ & 0.04 \\
Relatedness & 0.07 & 0.822 & -0.09 & 0.812 & 0.67 & 0.016 & -0.04 & 0.888 \\
Tenure & -0.32 & 0.269 & 0.15 & 0.706 & 0.02 & 0.946 & 0.30 & 0.267 \\
Age & -0.32 & 0.263 & 0.22 & 0.578 & -0.42 & 0.179 & 0.16 & 0.546 \\
Aggression & 0.05 & 0.861 & 0.03 & 0.915 & -0.18 & 0.586 & -0.16 & 0.555 \\
\hline
\end{tabular}

Table 4. Spearman's rank correlation coefficient between stand resting together (events hour ${ }^{-1}$ ) and length of tenure in the harem, age or aggression (frequency of aggressive acts hour ${ }^{-1}$ ) in each harem. Significance was $p>0.1$ in all correlations

(a) Including the stallion in the analysis

\begin{tabular}{lcccc}
\hline \multirow{2}{*}{ Factor } & \multicolumn{3}{c}{ Harem } \\
\cline { 2 - 5 } & Paritet & Bayan & Margad & Khaan \\
\hline Relatedness & 0.23 & 0.11 & 0.13 & 0.18 \\
Tenure & 0.10 & 0.06 & -0.37 & 0.09 \\
Age & -0.09 & 0.08 & -0.23 & 0.07 \\
Aggression & 0.09 & -0.12 & -0.41 & 0.09 \\
\hline
\end{tabular}

(b) Excluding the stallion in the analysis

\begin{tabular}{lcccc}
\hline \multirow{2}{*}{ Factor } & \multicolumn{3}{c}{ Harem } \\
\cline { 2 - 5 } & Paritet & Bayan & Margad & Khaan \\
\hline Relatedness & 0.32 & 0.06 & -0.19 & 0.31 \\
Tenure & 0.19 & -0.01 & -0.32 & 0.22 \\
Age & 0.03 & 0.01 & -0.29 & 0.23 \\
Aggression & 0.22 & -0.14 & -0.48 & 0.25 \\
\hline
\end{tabular}




\section{Discussion}

Associative behaviours were rare among the horses at HNP, occurring much less frequently than aggression. Other studies also found that these behaviours were rare (Wells \& von GoldschmidtRothschild, 1979; Carson \& Wood-Gush, 1983), but allogrooming was ten times less frequent at HNP than among Przewalski horses at San Diego Wild Animal Park (Mooring et al., 2000). Only one study found non-aggressive behaviours were more common than aggressive behaviours (Keiper \& Receveur, 1992), but this included nursing behaviour. More allogrooming was found in smaller enclosures than on a pasture (Hogan et al., 1988; Keiper \& Receveur, 1992), which may also have been the cause of the more frequent non-aggressive behaviours observed in the group in a reserve by Keiper \& Receveur (1992). Hogan et al. (1988) hypothesised that the constant proximity of horses within a small enclosure, and the lack of other stimuli, increased the probability of allogrooming, as well as aggression, among them. An extension of this hypothesis would be that horses without limits to their movements and no lack of stimuli, as at HNP, would allogroom or be aggressive as defined by the social structure of the harem, or as necessary to remove loose hair and parasites.

It was predicted that related animals would spend more time together and so more allogrooming and other associative behaviours would occur between them. However, although this was found in the Munich Zoo (Keiper, 1988), it was not seen in HNP, nor by Clutton-Brock et al. (1976) in highland ponies or by Mooring \& Hart (1995) in impalas. Some studies found that most associative behaviours occurred between horses that spent most time together (Clutton-Brock et al., 1976; Carson \& Wood-Gush, 1983; Feh, 1999), and that they tended to have preferred partners. Although in this study a large proportion of associative behaviour was between mares and their offspring, a similar proportion of interactions occurred between unrelated mares and between the mares and the stallion. This could reflect preferred partners of the same sex, and further study on whether stallions groom with mares more when they are in oestrus, as shown in primates (Di Bitetti, 1997), might be rewarding. High incidence of allogrooming during the spring breeding season lends some credence to this. However, this may also reflect the artificial formation of this population. Although the horses had free choice of social partners, the harem in which there was the greatest relationship between relatedness and grooming was also the only one that was formed naturally post-release. Time since release also had an effect on the frequency of allogrooming within a harem, suggesting that it takes time for animals to adjust to a new environment, and perhaps to become «associates».

Most interactions occurred between mares and juveniles at HNP. As mares and their offspring were often close together this is to be expected. The frequency of interactions between ages and sexes has been reported to vary in other studies. CrowellDavis et al. (1986) observed little allogrooming by or among adult horses and nearly half of all allogrooming observed by Keiper (1988) was by foals. When studying Przewalski's horses in a reserve however, Keiper \& Receveur (1992) found most allogrooming was initiated by mares. Exceptions to this are the population of mountain zebras in the Mountain Zebra National Park that had no preferred partners (Penzhorn, 1984), and no allogrooming at all was observed in Cape or Hartmann's Mountain zebras by Klingel (1968 in Feist, 1971).

The withers were groomed more than any other body part. It was this region that Feh \& de Mazieres (1993) found was associated with a reduced heart rate in horses and so hypothesised that it acted to reduce tension. There was no direct evidence that allogrooming reduced tension among the horses at HNP, as most occurred between mares and juveniles, but its function as weaning appeasement cannot be ruled out. Although allogrooming could have been acting to ameliorate acclimatisation stress, it is interesting that levels of grooming increased in the years following release.

There was no correlation between length of time in a harem, age or rank and frequency of allogrooming. One other study did not find any correlation between these factors either (CluttonBrock et al., 1976), but others found a correlation between allogrooming frequency and aggression (Feh \& Carton de Graumont, 1995), age (Keiper, 1988; Keiper \& Receveur, 1992), and rank (Keiper, 1988; Keiper \& Receveur, 1992; Kimura, 1998). Aggression occurred more often when horses were in an enclosed area as the increased proximity increased the likelihood of interactions (Hogan et al., 1988), but this is because horses do not allow all other individuals to come close to them. Stand resting together would therefore only occur between pairs of horses that allowed each other into their «personal space». Surprisingly, as with allogrooming, there were no correlations between stand resting together frequency or duration and 
relatedness or length of time in the harem, or other factors, but it is possible that this was due to the small sample size since both of these behaviours were rare.

In contrast to many group-living animals where grooming has an important social function, such as primates (e.g. Bentley-Condit \& Smith, 1999; Newton-Fisher \& Lee, 2011), unidirectional grooming was only seen once in our study. Unidirectional grooming in horses appears very rare: it was not reported during studies on allogrooming in the literature (e.g. Crowell-Davis et al., 1986; Keiper, 1988; Keiper \& Receveur, 1992; Kimura, 1998), and has only occasionally been reported by stallions on mares as a form of courtship (Houpt http://research.vet.upenn.edu accessed 28 July 2011). In equids it seems that if an individual does not respond to grooming overtures by another then the interaction ends immediately (Houpt \& Boyd, 1994); therefore unidirectional grooming is uncommon.

\section{Conclusions}

Most allogrooming occurred in the spring, when ticks were abundant, and autumn, when the horses were moulting, whereas other studies (Tyler, 1972; Kimura, 1998) observed most allogrooming in the summer. Our results imply a strong hygiene function of associative behaviours, and that they are stimulus driven, rather than a programmed response (Mooring et al., 2000). Horses cannot reach areas of their back and tail to scratch or remove hair except by rolling, so allogrooming is important for this. Stand resting together enables horses to keep flies away by whisking their tails around the head of a partner, thus it tended to be most frequent during the summer and/or the middle hours of the day, when flies were most active (King \& Gurnell, 2010). It is unlikely that associative behaviours have absolutely no social function and are purely for hygiene as they always occurred reciprocally between horses, although this could be to prevent cheating and is simply an example of evolved cooperation (Mooring \& Hart, 1995). Crowell-Davis et al. (1986) felt that allogrooming between females promoted bonding between horses and so acted as a basis for cohesiveness of a harem independently of the stallion. Most allogrooming occurred in the morning and evenings, when the horses were most active, suggesting that it is possible that it does occur to bond together members of the harem. However a function of allogrooming other than to remove hair and parasites could not be quantified here. Overall, we found no evidence of a social function of either allogrooming or stand resting together, but both occurred most frequently at times of year when they would be needed for coat care or to attempt to reduce the number of flies around the face. A social element of the behaviours cannot be ruled out as the sample size was small (due to the rarity of the behaviours) and further studies on associative behaviour in wild Przewalski's horses would be rewarding.

\section{Acknowledgements}

We thank the Foundation Reserves Przewalski's Horse for their financial support and the opportunity of studying the horses at Hustai National Park. Thanks to the Mongolian Association for the Conservation of Nature and the Environment and the staff at HNP for all their help during the study. Additional funding was provided by IFAW, Queen Mary Expeditions Committee and Marwell Preservation Trust.

\section{References}

Altmann J. 1974. Observational Study of Behavior: Sampling Methods. Behaviour 49(3-4): 227-267. DOI: 10.1163/156853974X00534

Barton R. 1985. Grooming site preferences in primates and their functional implications. International Journal of Primatology 6(5): 519-532. DOI: 10.1007/BF02735574

Bentley-Condit V., Smith, E. 1999. Female dominance and female social relationships among yellow baboons (Papio hamadryas cynocephalus). American Journal of Primatology 47(4): 321-324. DOI: 10.1002/(SICI)10982345(1999)47:4<321::AID-AJP4>3.0.CO;2-D

Boyd L., Houpt K. 1994. Activity patterns. In: L. Boyd, K. Houpt (Eds.): Przewalski's horse. The history and biology of an endangered species. Albany, NY: SUNY. P. 195-228.

Carson K., Wood-Gush D.G.M. 1983. Equine behaviour: I. A review of the literature on social and dam - Foal behaviour. Applied Animal Ethology 10(3): 165-178. DOI: 10.1016/0304-3762(83)90138-4

Clutton-Brock T.H., Greenwood P.J., Powell R.P. 1976. Ranks and relationships in Highland ponies and Highland cows. Zietschrift für Tierpsychologie 41(2): 202 216. DOI: 10.1111/j.1439-0310.1976.tb00477.x

Crowell-Davis S.L., Houpt K.A., Carini C.M. 1986. Allogrooming and nearest-neighbour relationships among foals of Equus caballus. Applied Animal Behaviour Science 15(2): 113-123. DOI: 10.1016/0168-1591(86)90057-2

Di Bitetti M.S. 1997. Evidence for an important social role of allogrooming in a platyrrhine primate. Animal Behaviour 54(1): 199-211. DOI: 10.1006/anbe.1996.0416

Dugdale H.L., Ellwood S.A., Macdonald D.W. 2010. Alloparental behaviour and long-term costs of mothers tolerating other members of the group in a plurally breeding mammal. Animal Behaviour 80(4): 721-735. DOI: 10.1016/j.anbehav.2010.07.011

Dunbar R.I.M. 1991. Functional significance of social grooming in primates. Folia Primatologica 57(3): 121131. DOI: $10.1159 / 000156574$ 
Feh C. 1999. Alliances and reproductive success in Camargue stallions. Animal Behaviour 57(3): 705-713. DOI: 10.1006/anbe. 1998.1009

Feh C., Carton de Graumont S. 1995. A natural herd of Przewalski horses on the Causse Mejean. P. Technical and scientific follow-up Spring 1993 - Spring 1995. Unpublished report.

Feh C., de Mazieres J. 1993. Grooming at a preferred site reduces heart rate in horses. Animal Behaviour 46(6): 1191-1194. DOI: 10.1006/anbe.1993.1309

Feist J. 1971. Behavior of feral horses in the Pryor Mountain Wild Horse Range. MSc Thesis. USA: University of Michigan.

Feist J. McCullough D. 1976. Behaviour patterns and communication in feral horses. Zietschrift für Tierpsychologie 41(4): 337-371. DOI: 10.1111/j.1439-0310.1976.tb00947.x

Gumert M.D. 2007. Payment for sex in a macaque mating market. Animal Behaviour 74(6): 1655-1667. DOI: 10.1016/j.anbehav.2007.03.009

Hart B.L., Hart L.A. 1992. Reciprocal allogrooming in impala, Aepyceros melampus. Animal Behaviour 44(6): 1073-1083. DOI: 10.1016/S0003-3472(05)80319-7

Henzi S., Barrett L. 1999. The value of grooming to female primates. Primates 40(1): 47-59. DOI: 10.1007/ BF02557701

Hillegass M., Waterman J., Roth J. 2008. The influence of sex and sociality on parasite loads in an African ground squirrel. Behavioural Ecology 19(5): 1006-1011. DOI: 10.1093/beheco/arn070

Hogan E.S., Houpt K.A., Sweeney K. 1988. The effect of enclosure size on social interactions and daily activity patterns of the captive Asiatic wild horse (Equus przewalskii). Applied Animal Behaviour Science 21(1-2): 147-168. DOI: 10.1016/0168-1591(88)90105-0

Houpt K., Boyd L. 1994. Social behaviour. In: L. Boyd, K. Houpt (Eds.): Przewalski's horse. The history and biology of an endangered species. Albany, NY: SUNY. P. 229-254.

Keiper R.R. 1976. Social organization of feral ponies. Procedures of Pennsylvania Academy of Science 50: 69-70.

Keiper R.R. 1988. Social interactions of the Przewalski horse (Equus przewalskii. Poliakov, 1881) herd at the Munich Zoo. Applied Animal Behaviour Science 21(1-2): 8997. DOI: 10.1016/0168-1591(88)90102-5

Keiper R., Receveur H. 1992. Social interactions of freeranging Przewalski horses in semi-reserves in the Netherlands. Applied Animal Behaviour Science 33(4): 303318. DOI: 10.1016/S0168-1591(05)80068-1

Kimura R. 1998. Mutual grooming and preferred associate relationships in a band of free-ranging horses. $A p$ plied Animal Behaviour Science 59(4): 265-276. DOI: 10.1016/S0168-1591(97)00129-9

King S. 2002. Home range and habitat use of free-ranging Prewalski horses at Hustai National Park, Mongolia. Applied Animal Behaviour Science 78(2-4): 103-113. DOI: $10.1016 / \mathrm{S} 0168-1591(02) 00087-4$

King S.R.B., Gurnell J. 2005. Habitat use and spatial dynamics of takhi introduced to Hustai National Park, Mongolia. Biological Conservation 124(2): 277-290. DOI: 10.1016/j.biocon.2005.01.034
King S.R.B., Gurnell J. 2007. Scent-marking behaviour by stallions: an assessment of function in a reintroduced population of Przewalski horses (Equus ferus przewalskii). Journal of Zoology 272(1): 30-36. DOI: 10.1111/j.1469-7998.2006.00243.x

King S.R.B., Gurnell J. 2010. Effects of fly disturbance on the behaviour of a population of reintroduced Przewalski horses (Equus ferus przewalskii) in Mongolia. Applied Animal Behaviour Science 125(1-2): 22-29. DOI: 10.1016/j.applanim.2010.03.006

Kutsukake N., Clutton-Brock T.H. 2006. Social functions of allogrooming in cooperatively breeding meerkats. Animal Behaviour 72(5): 1059-1068. DOI: 10.1016/j. anbehav.2006.02.016

Kutsukake N., Clutton-Brock T.H. 2010. Grooming and the value of social relationships in cooperatively breeding meerkats. Animal Behaviour 79(2): 271-279. DOI: 10.1016/j.anbehav.2009.10.014

Lewis R.J. 2010. Grooming patterns in Verreaux's sifaka. American Journal of Primatology 72(3): 254-261. DOI: 10.1002/ajp.20776

Linklater W.L. 2000. Adaptive explanation in socio-ecology: lessons from the Equidae. Biological Review 75(1): 1-20. DOI: 10.1111/j.1469-185X.1999.tb00039.x

Matsuno K., Urabe M. 1999. Male-female interactions of sika deer (Cervus nippon) in Nara Park through allogrooming during breeding and rutting seasons. Journal of Ethology 17(1): 41-49. DOI: 10.1007/BF02769296

Mooring M.S., Benjamin J.E., Harte C.R., Herzog N.B. 2000. Testing the interspecific body size principle in ungulates: the smaller they come the harder they groom. Animal Behaviour 60(1): 35-45. DOI: 10.1006/ anbe.2000.1461

Mooring M.S., Hart B.L. 1992. Reciprocal allogrooming in dam-reared and hand-reared impala fawns. Ethology 90(1): 37-51. DOI: 10.1111/j.1439-0310.1992.tb00818.x

Mooring M.S., Hart B.L. 1995. Costs of allogrooming in impala: Distraction from vigilance. Animal Behaviour 49(5): 1414-1416. DOI: 10.1006/anbe.1995.0175

Mott C., Bloomquist C., Nielsen C. 2011. Seasonal, diel, and ontogenetic patterns of within-den behavior in beavers (Castor canadensis). Mammalian Biology 76(4): 436444. DOI: 10.1016/j.mambio.2010.09.002

Newton-Fisher N.E., Lee P.C. 2011. Grooming reciprocity in wild male chimpanzees. Animal Behaviour 81(2): 439-446. DOI: 10.1016/j.anbehav.2010.11.015

Noldus Information Technology. 1998. MatMan, Reference Manual. Version 1.0 for Windows.

Norval R., Sutherst R., Kurki J., Gibson J., Kerr J. 1988. The effect of the brown ear-tick Rhipicephalus appendiculatus on the growth of Sanga and European Breed cattle. Veterinary Parasitology 30(2): 149-164. DOI: 10.1016/0304-4017(88)90162-8

Penzhorn B.L. 1984. A long term study of social organisation and behaviour of Cape mountain zebra Equus zebra zebra. Zietschrift für Tierpsychologie 64(2): 97-146. DOI: 10.1111/j.1439-0310.1984.tb00355.x

Sato S., Tarumizu K., Hatae K. 1993. The influence of social factors on allogrooming in cows. Applied Animal Be- 
haviour Science 38(3-4): 235-244. DOI: 10.1016/01681591(93)90022-H

Schino G., Scucchi S., Maestripieri D., Turillazzi P.G. 1988. Allogrooming as a tension-reduction mechanism: a behavioural approach. American Journal of Primatology 16(1): 43-50. DOI: 10.1002/ajp.1350160106

Schino G. 2007. Grooming and agonistic support: a meta-analysis of primate reciprocal altruism. Behavioural Ecology 18(1): 115-120. DOI: 10.1093/ beheco/ar1045

Schino G., Aureli F. 2010. The relative roles of kinship and reciprocity in explaining primate altruism. Ecology Letters 13(1): 45-50. DOI: 10.1111/j.1461-0248.2009.01396.x

Sigurjónsdóttir H., van Dierendonck M., Snorrason S., Thórhallsdóttir A.G. 2003. Social relationships in a group of horses without a mature stallion. Behaviour 140(6): 783-804. DOI: $10.1163 / 156853903322370670$
Stewart P., Macdonald D. 2003. Badgers and badger fleas: strategies and counter-strategies. Ethology 109(9): 751764. DOI: 10.1046/j.1439-0310.2003.00910.x

Tyler S.J. 1972. The behaviour and social organization of the New Forest ponies. Animal Behaviour Monographs 5(2): 85-196. DOI: 10.1016/0003-3472(72)90003-6

van den Bos R. 1998. The function of allogrooming in domestic cats (Felis silvestris catus): a study in a group of cats living in confinement. Journal of Ethology 16(1): 1-13. DOI: 10.1007/BF02896348

Wallis de Vries M.F., Manibazar N., Dugerlham S. 1996. The vegetation of the forest-steppe region of Hustain Nuruu, Mongolia. Vegetatio 122(2): 111-127. DOI: 10.1007/ BF00044694

Wells S., von Goldschmidt-Rothschild B. 1979. Social behaviour and relationships in a herd of Camargue horses. Zietschrift für Tierpsychologie 49(4): 363-380. DOI: 10.1111/j.1439-0310.1979.tb00299.x

\title{
АССОЦИАТИВНОЕ ПОВЕДЕНИЕ У ЛОШАДЕЙ ПРЖЕВАЛЬСКОГО, РЕИНТРОДУЦИРОВАННЫХ В МОНГОЛИИ
}

\author{
С. Р. Б. Кинг ${ }^{1,2, *}$, Дж. Гарнелл ${ }^{1}$ \\ ${ }^{1}$ Лондонский университет королевы Марии, Великобритания \\ ${ }^{2}$ Государственный университет Колорадо, США \\ *e-mail: sarah.king@colostate.edu
}

\begin{abstract}
Аллогруминг - важное поведение общественных млекопитающих, выполняющее гигиенические и/или социальные функции и может быть обусловлено родственными связями или сотрудничеством. Эквиды демонстрируют аллогруминг и другое ассоциативное поведение, стоя на отдыхе рядом друг с другом. Мы исследовали закономерности такого поведения в четырех гаремах лошадей Пржевальского Equиs ferus przewalskii, реинтродуцированных в Монголии, чтобы оценить, были ли они поведением, выполняющим лишь гигиеническую, а не социальную функцию. Мы провели 860 часов наблюдений в течение 15 месяцев в период с апреля 1998 г. по июль 2000 г. Аллогруминг был нечастым (средняя частота - 0.02 акта на 1 особь в час, $\mathrm{n}=363$ акта, IQR $=0-0.06)$, он чаще затрагивал холку (62\% наблюдений), чем любую другую часть тела. Аллогруминг чаще наблюдался весной и осенью, а также утром и вечером. Ни в одном гареме не было никакой существенной корреляции между частотой аллогруминга и родством партнеров, рангом в иерархии доминирования, продолжительностью пребывания, тем, меняла ли особь группу, возрастом или количеством агрессий. Отдых, стоя рядом друг с другом, наблюдался реже, чем аллогруминг (средняя частота 0.00 акта на 1 особь в час, $\mathrm{n}=335, \mathrm{IQR}=0-0.014$ ). В отличие от аллогруминга, отдых, стоя рядом друг с другом, обычно наблюдался весной, и это происходило чаще в середине дня. Не было никаких существенных различий между гаремами, а также степенью родства и частотой отдыха стоя рядом друг с другом в любом гареме, а также не было связи с возрастом и сроком пребывания в гареме. В целом, мы не нашли никаких свидетельств социальной функции, связанной с аллогрумингом или отдыхом, стоя рядом друг с другом, но обе эти формы поведения встречались чаще в те времена года, когда они были необходимы для ухода за шерстью или для уменьшения количества насекомых около морды. Эти результаты подтверждают нашу гипотезу о том, что ассоциативное поведение являлось просто взаимными гигиеническими процедурами, без каких-либо доказательств того, что выбор был связан со степенью родства, хотя социальный компонент такого поведения не может быть полностью исключен.
\end{abstract}

Ключевые слова: Equus ferus przewalskii, аллогруминг, взаимность, взаимный груминг, гигиена, родство 